\title{
'Obligatory' Association Between A and D Cells Demonstrated by Bipolar Islets in Neonatal Pancreas
}

Sir,

There seems to be a consistent pattern of arrangement of the various endocrine cells in the islets of Langerhans [1]. Typically, an islet has a central core of insulin (B) cells surrounded by a peripheral mantle of non-B cells: glucagon (A), somatostatin (D) and pancreatic polypeptide. While neonatal human islets fit this pattern, adult human islets have been frequently described as having a random arrangement of endocrine cells. However, since in the adult human islet, $A$ and $D$ cells border the large penetrating
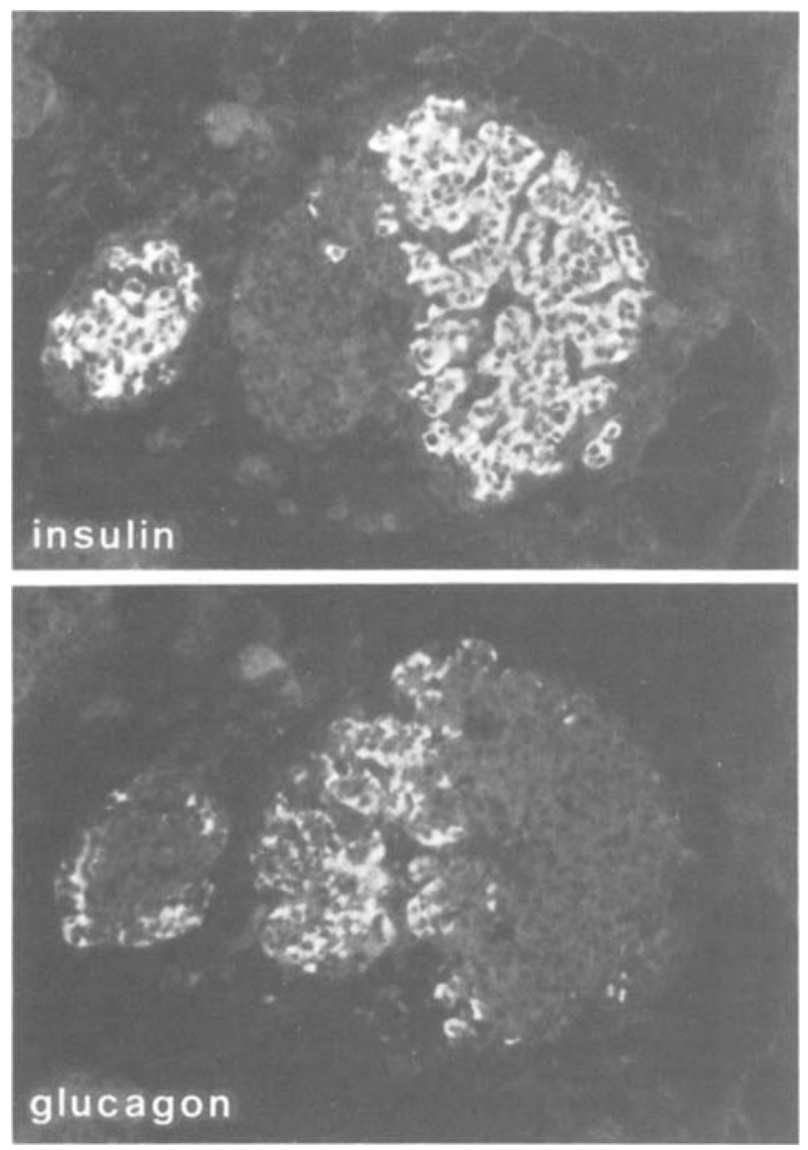

vessels and surround more centrally located B cells, this islet can be seen as a multiple of smaller units consisting of central $B$ cells and peripheral non-B cells [2]. Thus $A$ and $D$ cells seem to be preferentially associated with one another, a recurrent topographical relationship which led to the hypothesis that the nonrandom arrangement of islet cells may be functionally based $[3,4]$. The assumption that the association of A and D cells is "obligatory" underlies this hypothesis and now appears justified by the neonatal pancreas described below.

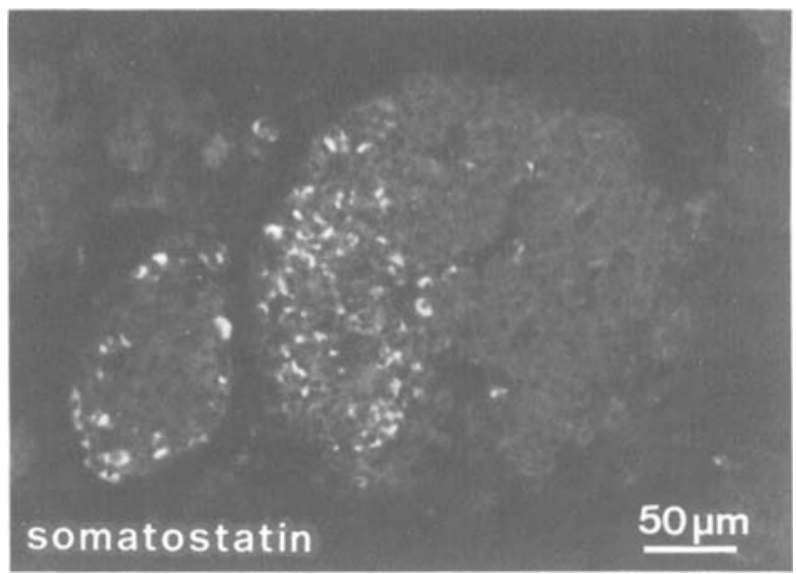

Fig. 1. Consecutive serial sections of newborn pancreas (glucagonrich portion) stained for immunofluorescence with anti-insulin, anti-glucagon and anti-somatostatin antisera. The photographic field illustrates a small and a large islet with a different pattern of arrangement of endocrine cells. Insulin-containing cells (B cells) form the centre of the small islet (left) and are surrounded by a mantle of glucagon and somatostatin cells. In the large islet, insulin cells are restricted to the right part, while glucagon and somatostatin cells are concentrated to the left (bipolar islet). In spite of this bipartition the two latter cell types maintain topographical proximity. $\times 190$ 
The pancreas was that of a male infant ( 36 weeks gestation, weight $2,680 \mathrm{~g}, 1.46 \mathrm{~cm}$ ) who died three days after birth from a respiratory arrest. The autopsy reported multiple malformations including acrocephalosyndactyly, craniofacial dysostosis, mobile caecum, oesophageal cysts and micro-cystic kidneys. The pancreas was systemically sampled as previously described [5], fixed in Bouin's fluid and embedded in paraffin. Adjacent sections were stained by indirect immunofluorescence for the four islet hormones [6].

As shown in Figure 1, two types of islets were found in the glucagon-rich region of the pancreas (anterior part of the head, body and tail) [5]; the most frequent islets were small to medium sized (diameter range 20-60 $\mu \mathrm{m}$ ) and showed the characteristic central core of $B$ cells surrounded by a peripheral mantle of A- and D-cells. The lesser frequent islets consisted of large units (diameter range $100-210 \mu \mathrm{m}$ ), usually bordering or lying entirely in the fibrous connective septa. About $20 \%$ of this second type appeared bipolar, that is the B cells were grouped at one pole and A- and Dcells at the other. Bipolar islets, which have been reported as normally occurring in last trimester fetuses and in neonates [7-9], provide an example of an atypical pattern of islet organization. Nevertheless the close association of A and D cells is maintained. The constancy of this preferential association supports the concept of a necessary interaction between these two cell types for the proper secretory behaviour of the endocrine pancreas.

L. Orci, Y. Stefan, S. Bonner-Weir, A. Perrelet and R. Unger

\section{References}

1. Orci L, Perrelet A (1979) La microarchitecture des îlots de Langerhans. Pour la Science 22: 30-44

2. Orci L (1977) A multihormonal micro-organ. In: Bajaj JS (ed)
Insulin and Metabolism. Excerpta Medica, Amsterdam, pp $1-11$

3. Orci L, Unger R (1975) Functional subdivision of islets of Langerhans and possible role of D cells. Lancet II: 1243-1244

4. Unger RH, Dobbs RE, Orci L (1978) Insulin, glucagon and somatostatin secretion in the regulation of metabolism. Ann Rev Physiol 40: 307-343

5. Orci L, Malaisse-Lagae F, Baetens D, Perrelet A (1978) Pancreatic polypeptide-rich regions in human pancreas. Lancet II: 1200-1201

6. Coons AH, Leduc EH, Connolly JM (1955) Studies on antibody production. I. A method for the histochemical demonstration of specific antibody and its application to a study of the hyperimmune rabbit. J Exp Med 102: 49-63

7. Robb P (1961) The development of the islet of Langerhans in the human foetus. J Exp Physiol 46: 335

8. Falin LI (1967) The development and cytodifferentiation of the islets of Langerhans in human embryos and foetuses. Acta Anat (Basel) 68: 147-168

9. Jaffe R, Hashida Y, Yunis EJ (1980) Pancreatic pathology in hyperinsulinemic hypoglycemia of infancy. Lab Invest 42 : 356-365

L. Orci

Institute of Histology and Embryology

University of Geneva Medical School

CH-1121 Geneva 4, Switzerland

\section{Exercise and Diabetes}

Dear Sir,

Drs Sherwin and Koivisto (Diabetologia (1981) 20: 84) present an admirably balanced review of the literature concerning exercise and diabetes. However, at the end they step resolutely off the fence, asking themselves the question "should the current lack of hard evidence dissuade us from recommending a planned programme of exercise to our diabetic patients?" They answer this with a qualified 'Yes,' the qualifications including pre-screening for underlying disorders (what, precisely?) and an individualised programme of exercise.

I don't know what things are like in New Haven, but most clinics in my experience have enough to do in just coping with their diabetics and most physicians will readily admit that their degree of success in persuading patients to follow their conventional recommendations is modest. Furthermore, most new diabetics are above the age of 50 years. How easy will it be to persuade them to participate in the relatively considerable degree of exercise required to produce the changes in plasma lipids, insulin sensitivity, etc. reported? Long term experience with volunteer non-diabetics is not very encouraging $[1,2]$. And what resources should we devote to pre-screening and provision of facilities? And how would we feel after devoting such effort if someone actually did a prospective trial of exercise in diabetics and showed it to be of no value, or even harmful?
For my part, I shall continue to encourage diabetics to exercise if they ask me. But I shall avoid 'recommendations' until there is hard evidence of benefit.

Yours faithfully

R. J. Jarrett

\section{References}

1. Ilmarinen J, Fardy PS (1977) Physical activity intervention for males with high risk of coronary heart disease: a three year follow-up. Prev Med 6: 416-425

2. Sedgwick AW, Brotherhood JR, Harris-Davidson A, Taplin RE, Thomas DW (1980) Long term effects of physical training programme on risk factors for coronary heart disease in otherwise sedentary men. Br Med J 281: 7-10

\section{R. J. Jarrett}

Department of Community Medicine

Guy's Hospital Medical School

London Bridge, SE1 9RT, UK 